\title{
Reduction of fuel consumption using driving strategy in agricultural tractor
}

\author{
Marcelo S. de Farias ${ }^{1}$, José F. Schlosser², Pilar Linares ${ }^{3}$, Gilvan M. Bertollo ${ }^{4}$ \& Alfran T. Martini ${ }^{5}$ \\ ${ }^{1}$ Universidade Federal de Santa Maria/Departamento de Ciências Agronômicas e Ambientais. Frederico Westphalen, RS. E-mail: silveira_farias@hotmail.com \\ (Corresponding author) - ORCID: 0000-0002-2949-1320 \\ ${ }^{2}$ Universidade Federal de Santa Maria/Centro de Ciências Rurais/Departamento de Engenharia Rural. Santa Maria, RS. E-mail: josefernandoschlosser@gmail.com - \\ ORCID: 0000-0002-4906-3147 \\ ${ }^{3}$ Universidad Politécnica de Madrid/Escuela Técnica Superior de Ingenieros Agrónomos/Departamento de Ingeniería Agroforestal. Madrid, España. \\ E-mail: pilar.linares@upm.es - ORCID: 0000-0003-0574-7528 \\ ${ }^{4}$ Universidade Regional do Noroeste do Estado do Rio Grande do Sul/Departamento de Estudos Agrários. Ijuí, RS. E-mail: gilvanbertollo@yahoo.com.br - \\ ORCID: 0000-0002-8443-6711 \\ ${ }^{5}$ Universidade Federal de Santa Maria/Coordenadoria Acadêmica. Cachoeira do Sul, RS. E-mail: alfrantm@gmail.com - ORCID: 0000-0003-0176-0864
}

ABSTRACT: During the acquisition and use of an agricultural tractor, the consumption of fuel by the engine must be taken into account by the user, considering its nonrenewable origin and the marketing price. Appropriate strategies in driving tractors can help users to reduce production costs. In this context, the objective of this study was to evaluate the fuel consumption of an agricultural tractor using different driving strategies. Load levels were imposed, following the instructions from Organization for Economic Co-operation and Development Code 2, using an instrumented dynamometer car, in a concrete test track. Six load levels (30, 40, 50, 60, 70, and $80 \%$ of Q0) and three travel speeds $\left(5.16,7.29\right.$, and $\left.10.48 \mathrm{~km} \mathrm{~h}^{-1}\right)$ were applied for the strategies used (Full Throttle and Shifted Up - Throttle Back), where Q0 is the traction force corresponding to the maximum power in the drawbar for each gear selected. Three repetitions were made, which totaled 108 experimental units $(2 \times 3 \times 6 \times 3)$, in a completely randomized experimental design. Shifted Up - Throttle Back mode should be used as a strategy of tractor driving, because it can save up to $29.39 \%$ of fuel in relation to the Full Throttle mode, typically used by users.

Key words: concrete test track, load levels, energy efficiency

\section{Redução do consumo de combustível usando estratégia de condução em trator agrícola}

RESUMO: No momento da aquisição e utilização de um trator agrícola, o consumo de combustível pelo motor deve ser levado em conta pelo usuário, tendo em vista sua origem não renovável e o preço de comercialização. Estratégias adequadas de condução de tratores podem auxiliar os usuários a reduzirem os custos de produção. Nesse contexto, objetivou-se avaliar o consumo de combustível de um trator agrícola utilizando diferentes estratégias de condução. Cargas parciais foram impostas, seguindo instruções contidas no Código 2 da Organização para a Cooperação e Desenvolvimento Econômico, utilizando carro dinamométrico instrumentado, em pista de concreto. Foram aplicadas seis cargas parciais (30; 40; 50; 60; 70 e 80\% de Q0) e três velocidades de deslocamento $\left(5,16 ; 7,29\right.$ e 10,48 $\left.\mathrm{km} \mathrm{h}^{-1}\right)$, para as estratégias utilizadas (Aceleração Máxima; e Marcha Longa - Aceleração Reduzida), onde Q0 é a força de tração correspondente à potência máxima na barra de tração, para cada marcha selecionada. Foram realizadas três repetições, que totalizaram 108 unidades experimentais $(2 \times 3 \times 6$ × 3), em um delineamento experimental inteiramente casualizado. $\mathrm{O}$ modo Marcha Longa - Aceleração Reduzida deve ser utilizado como uma estratégia de condução do trator, pois pode-se economizar até 29,39\% de combustível em relação ao modo Aceleração Máxima, normalmente utilizado pelos usuários.

Palavras-chave: pista de teste de concreto, cargas parciais, eficiência energética 


\section{INTRODUCTION}

Alternative managing options for mechanized agricultural operations are being searched for, more specifically for the main source of power for them, the farm tractor, because of the costs of fuel, pollution generated by their combustion, and the necessity of diminishing energy consumption (Frantz et al., 2014). Tractor use in rural areas is very diverse, and the search for the optimized performance is justifiable (Vale et al., 2011).

While acquiring a tractor, the user usually considers technical and economic criteria; however, in addition, energy efficiency is another important factor to be analyzed (Silveira \& Sierra, 2010). Considering that the cost of the energy used in machine operations has a significant impact on the total cost of mechanization, it can be reduced through improvement of the operational procedures (Stange et al., 1984); most of these procedures can be done by the owner, because they are about changing the functioning parameters of the machines (Márquez, 2012).

In this way, there is a necessity for knowledge about factors that may interfere with fuel consumption, so it can be as efficient as possible. Thus, according to Kim et al. (2013), it is important to analyze the effects of gear selection during mechanized agricultural operations. Different consumptions may be obtained for the same type of work, depending on the gear being used (Hansson et al., 2003).

Driving strategies are the answer to manage engine and transmission, aiming to reduce fuel consumption, and therefore, obtain higher efficiency in diesel oil use (Howard et al., 2013). This technique was described by Grisso et al. (2014a) as "Gear Up - Throttle Down" or "Shift Up - Throttle Back" (SUTB). According to the authors, this is a fuel-saving practice that can be used when the load in the drawbar power is lower (less than 75\% of nominal power) and power take-off (PTO) speed is reduced.

Because of the necessity of obtaining more energy efficiency in agricultural use of tractors, the objective of this study was to evaluate the fuel consumption in a tractor using different driving strategies.

\section{Material ANd Methods}

\section{Research tractor}

In the experiment conducted in a concrete test track at the Mechanic Agriculture Station, Madrid, Spain (40²1'
34.77" N; 30 43' 20.38” W; 613 m), a MF 7616 Dyna-6 tractor (Massey Ferguson, Beauvais, France) was used, equipped with a four-stroke diesel cycle engine (66 AWI 695) from the same manufacturer, with six cylinders, a dislocated volume of $6.596 \mathrm{~cm}^{3}$, and a turbocharger with an intercooler. According to the test report, its maximum power and torque are $105.3 \mathrm{~kW}$ at $1998 \mathrm{rpm}$ and $615.8 \mathrm{Nm}$ at $1100 \mathrm{rpm}$, respectively (IRSTEA, 2013). The power transmission system was equipped with a hydrostatic gearbox-type Powershift, with 24 gears forward and 24 reverse. The tractor had a total weight of 7,660 kg $(75.14 \mathrm{kN})$, with a static mass distribution of $61 \%$ on the rear axle and $39 \%$ on the front axle.

\section{Data acquisition}

Fuel consumption was measured by the volumetric flow meter installed in the dynamometer car connected to the tractor, which applied level-controlled loads in the drawbar and housed the measuring device. The car braked the test tractor by means of a hydraulic circuit with a variable displacement pump. The car braking was given through a hydraulic circuit with a variable displacement pump. The dynamometer car had a maximum traction capacity of 15,000 kgf (147.15 kN), and its mass for the experiment's performance was $17,85 \mathrm{~kg}$ $(175.11 \mathrm{kN})$. The experimental layout is shown in Figure 1.

The tractor's fuel consumption data were sent to the dynamometer car computer in real time every second, through a data transfer center positioned within the tractor cab. Before the experiment, the engine of the tractor had been run for $30 \mathrm{~h}$ using an electric dynamometer brake connected to the tractor by the PTO, where a load equivalent to $30 \%$ the nominal power provided by the manufacturer was applied.

\section{Test method and procedure}

Because of the engine speed and the transmission relation of each gear, driving strategies were determined for the tractor. The gears 8 (2B), 10 (2D), and 14 (3B) (Figure 2) were used, which, for maximum engine speed without load $(2,153 \mathrm{rpm})$, corresponded to travel speeds of 5.16, 7.29, and $10.48 \mathrm{~km} \mathrm{~h}^{-1}$, respectively. The travel speed variation of 5 and $11 \mathrm{~km} \mathrm{~h}^{-1}$ was proposed to include a vast diversity of agricultural operations performed on the field.

To balance the same travel speeds proposed (5.16, 7.29, and $\left.10.48 \mathrm{~km} \mathrm{~h}^{-1}\right)$, a lower engine speed was selected $(1,524$

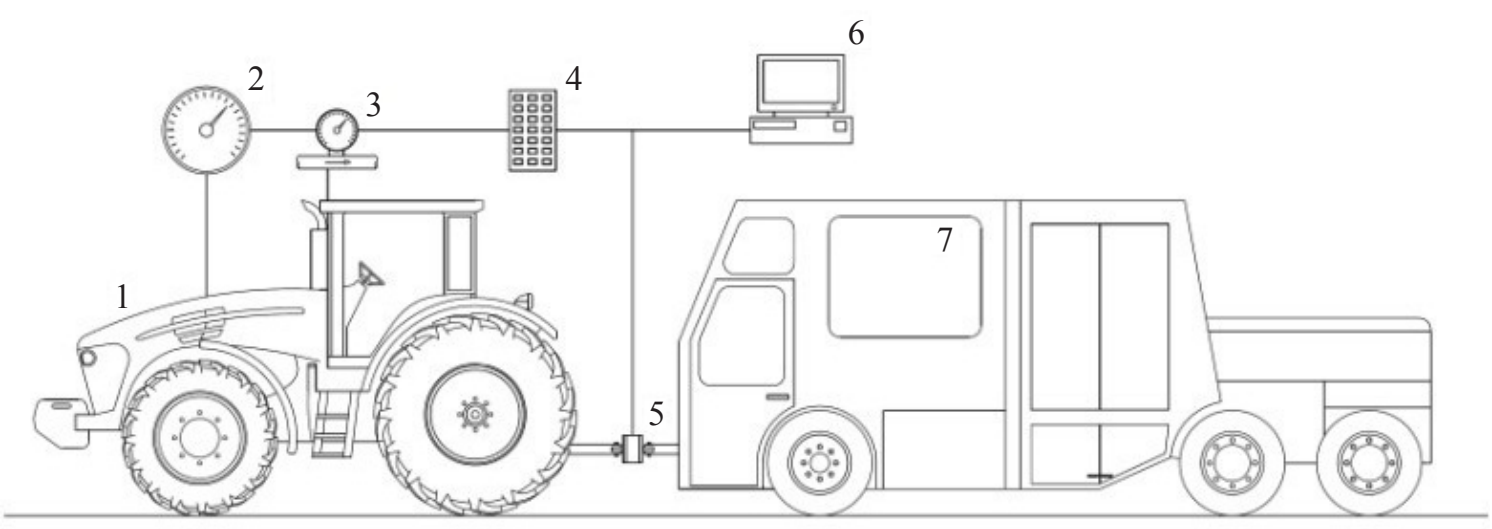

1. Agricultural tractor; 2. Engine speed; 3. Fuel consumption; 4. Central data transfer; 5. Drawbar power; 6. Software of performance parameters and breaking control; 7. Dynamometer car

Figure 1. Schematic representation of the experiment to obtain the parameters of fuel consumption efficiency 


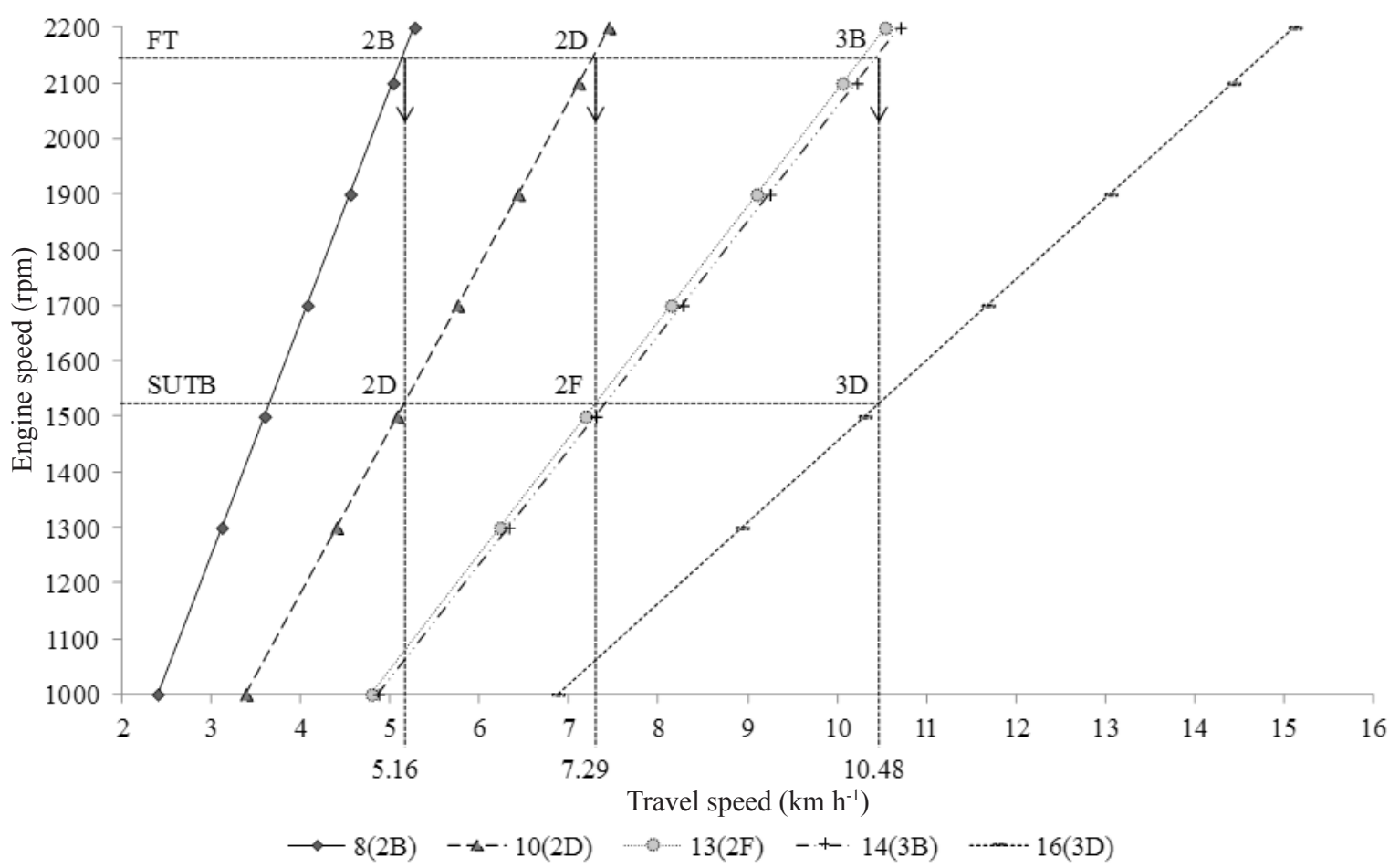

Figure 2. Engine speeds and work gears used that configure Full Throttle (FT) and Shifted Up - Throttle Back (SUTB) driving modes, as well as travel speeds, for the MF 7616 Dyna-6 tractor (Massey Ferguson, Beauvais, France)

rpm), although, when shifted up, gears $10(2 \mathrm{D}), 13(2 \mathrm{~F})$, and 16 (3D) (Figure 2) were used. Thus, two driving strategies were characterized: Full Throttle (FT) and Shifted Up - Throttle Back (SUTB). A schematic representation of the engine speeds and gears used in the experiment is shown in Figure 2.

The load levels applied in the tractor were obtained from previous official tests, following the instructions from the Organization for Economic Co-operation and Development (OECD, 2014). For each gear selected, an initial engine speed of 2,153 rpm determined the traction force $(\mathrm{Q} 0)$ corresponding the maximum power in the drawbar. Then, traction forces of $61.14 \mathrm{kN}$ for gear $2 \mathrm{~B}, 1,995 \mathrm{rpm}$ from the engine; $46.43 \mathrm{kN}$ for $2 \mathrm{D}$, with $1,984 \mathrm{rpm}$; and $34.71 \mathrm{kN}$ for $3 \mathrm{~B}$, with $1,978 \mathrm{rpm}$ were obtained.

Afterward, for the two driving strategies evaluated, six load levels were applied to each gear $(30,40,50,60,70$, and $80 \%$ of $\mathrm{Q} 0)$. Because of the electronic fuel injection system, even with a lower engine speed and longer gears, the tractor withstood the load levels applied.

\section{Experimental and statistical procedures}

The hourly $\left(\mathrm{L} \mathrm{h}^{-1}\right)$ and specific $\left(\mathrm{g} \mathrm{kW}^{-1} \mathrm{~h}^{-1}\right)$ fuel consumption of the engine were analyzed according to a design based on three factors, resulting in two driving strategies, three travel speeds, and six load levels applied to the tractor. Three repetitions were made, which totaled 108 experimental units (2 $\times 3 \times 6 \times 3$ ), in a completely randomized experimental design, due to surface uniformity, using a concrete test track.

First, data were analyzed regarding its normality and homoscedasticity. Then, variables were submitted to an analysis of variance $(\rho \leq 0.05)$. When there was significance, the averages were analyzed by a Tukey test $(\rho \leq 0.05)$. For this purpose, Sisvar version 5.3 software was used (Ferreira, 2011).

\section{RESUlTS AND Discussion}

After a variance analysis of the results of hourly and specific fuel consumption for the driving modes, travel speeds, and load levels evaluated, it was verified that the variables presented statistical difference (Table 1).

Table 1. Summary of the analysis of variance for the hourly $\left(\mathrm{Lh}^{-1}\right)$ and specific $\left(\mathrm{g} \mathrm{kW}^{-1} \mathrm{~h}^{-1}\right)$ fuel consumption parameters

\begin{tabular}{|c|c|c|c|}
\hline \multirow{2}{*}{$\begin{array}{l}\text { Sources } \\
\text { of variation }\end{array}$} & \multirow{2}{*}{$\begin{array}{l}\text { Degrees } \\
\text { of freedom }\end{array}$} & \multicolumn{2}{|c|}{ Average squares } \\
\hline & & $\begin{array}{l}\text { Hourly fuel } \\
\text { consumption }\end{array}$ & $\begin{array}{l}\text { Specific fuel } \\
\text { consumption }\end{array}$ \\
\hline Strategy (S) & 1 & 308.05 & 126869.60 \\
\hline Travel speed (T) & 2 & 62.34 & 971.12 \\
\hline Load level (L) & 5 & 302.77 & 42447.87 \\
\hline$S \times T$ & 2 & 2.15 & 721.69 \\
\hline$S \times L$ & 5 & 1.17 & 4586.43 \\
\hline$T \times L$ & 10 & 1.63 & 255.59 \\
\hline$S \times T \times L^{*}$ & 10 & 0.21 & 207.89 \\
\hline Residue & 72 & 0.04 & 17.56 \\
\hline Fc $(S \times T \times L)$ & & 4.89 & 11.84 \\
\hline CV (\%) & & 1.06 & 1.23 \\
\hline
\end{tabular}

* Differ statistically $(\rho \leq 0.05)$

\section{Hourly fuel consumption}

The use of the driving strategy SUTB had the lowest consumption, in all load levels and travel speeds, when compared to FT (Figure 3). Depending on the project of the engine and other controlling factors, such as the fuel supply system, this driving strategy can provide fuel savings of 12 to $30 \%$. Even with a low traction force, the fuel consumption for the same power was higher when engine speed was elevated.

For each travel speed, while the average load levels are incremented, the fuel consumption increases. According to Howard et al. (2013), the hourly fuel consumption is a linear function of the drawbar power (Figure 3). 


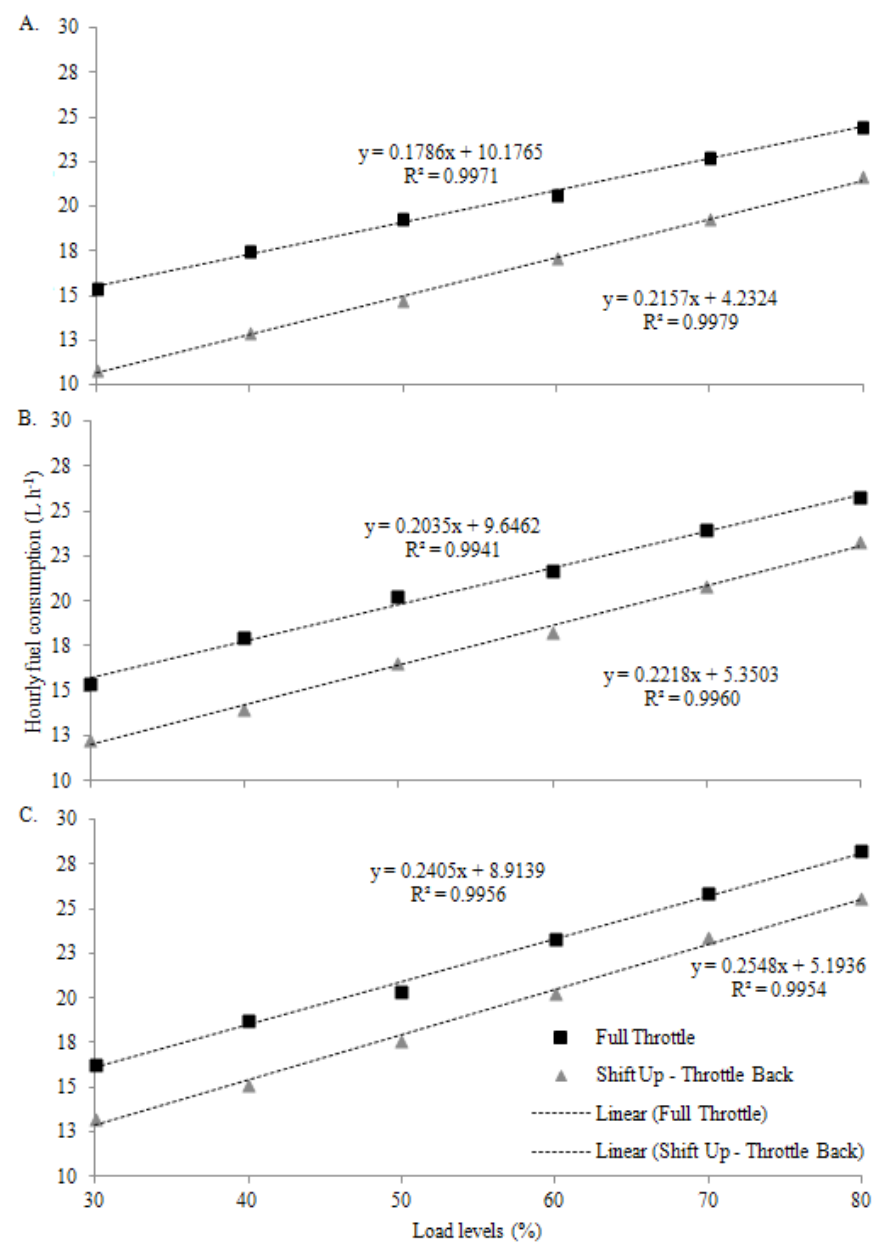

Figure 3. Hourly fuel consumption regarding the load levels applied to the tractor using two driving strategies for three travel speeds: (A) 5.16, (B) 7.29 and (C) $10.48 \mathrm{~km} \mathrm{~h}^{-1}$

From the regression equations presented in Figure 3A, an increase of 1.79 and $2.15 \mathrm{~L} \mathrm{~h}^{-1}$ is observed for each $10 \%$ increase in load levels applied on the tractor, for FT and SUTB, respectively. Transitory load levels applied on the tractor engine significantly affect fuel consumption, and for agricultural operations where the engine speed and torque variations are small, the effect on fuel efficiency is lower (Hansson et al., 2003).

The results presented in Table 2 show that, for all combinations, there was a difference between the two driving modes and six load levels, where hourly consumption varied from $10.86 \mathrm{~L} \mathrm{~h}^{-1}$ for SUTB, at $5.16 \mathrm{~km} \mathrm{~h}^{-1}$, to $28.27 \mathrm{~L} \mathrm{~h}^{-1}$ for FT at $10.48 \mathrm{~km} \mathrm{~h}^{-1}$. With the tractor being driven SUTB, engine fuel consumption was reduced, providing savings of up to $29.39 \%$ of fuel when compared with FT.

This percentage difference is lower as the applied load levels increase (Figure 3); however, it is statistically different between the modes. According to the American Society of Agricultural Engineers (ASAE, 2006), fuel consumption varies depending on its type, density, and viscosity and on engine applied load level percentage.

For a tractor operating with a load level of $50 \%$ of the maximum drawbar power, at a travel speed of $7.29 \mathrm{~km} \mathrm{~h}^{-1}$, the potential fuel saving is $18.38 \%\left(20.24 \mathrm{~L} \mathrm{~h}^{-1}\right.$ with FT as opposed to $16.52 \mathrm{~L} \mathrm{~h}^{-1}$ with SUTB). The annual fuel saving from different driving strategies can be estimated by the multiplication of the total number of hours for which the tractor is used annually in agricultural operations by the difference of fuel consumption (Grisso et al., 2014b).

Considering the price paid for one liter of mineral diesel, the consumption reduction, and consequently, the cost of tractor work are important to justify the use of the SUTB strategy instead of FT. In addition, fuel combustion is an important source of pollutant gas emission (Estrada et al., 2016), resulting in considerable impact on the environment and human health (Lindgren et al., 2011).

\section{Specific fuel consumption (SFC)}

SFC was reduced while the applied load level was increased in the tractor (Figure 4), corroborating data obtained by

Table 2. Hourly $\left(\mathrm{L} \mathrm{h}^{-1}\right)$ and specific $\left(\mathrm{g} \mathrm{kW}^{-1} \mathrm{~h}^{-1}\right)$ fuel consumption averages for Full Throttle (FT) and Shifted Up - Throttle Back (SUTB) driving strategies, in all three travel speeds and six load levels applied to the tractor

\begin{tabular}{|c|c|c|c|c|c|c|}
\hline \multirow{2}{*}{ Modes } & \multicolumn{6}{|c|}{ Load levels (\%) } \\
\hline & 30 & 40 & 50 & 60 & 70 & 80 \\
\hline \multicolumn{7}{|c|}{$\begin{array}{l}\text { Hourly fuel consumption }\left(\mathrm{L} \mathrm{h}^{-1}\right) \\
\qquad 5.16 \mathrm{~km} \mathrm{~h}^{-1}\end{array}$} \\
\hline FT & $15.38 \beta A a$ & $17.48 \beta A b$ & $19.32 \beta A C$ & $20.64 \mathrm{BAd}$ & $22.71 \beta \mathrm{Ae}$ & $24.48 \beta A f$ \\
\hline SUTB & $10.86 \alpha A a$ & $12.94 a A b$ & $\begin{array}{l}14.70 \alpha \mathrm{Ac} \\
\quad 7.29 \mathrm{~km} \mathrm{~h}^{-1}\end{array}$ & $17.10 \alpha \mathrm{Ad}$ & $19.32 \alpha \mathrm{Ae}$ & $21.66 \alpha A f$ \\
\hline FT & $15.37 \beta A a$ & $18.00 \beta \mathrm{Bb}$ & $20.24 \beta B c$ & $21.72 \beta \mathrm{Bd}$ & $23.96 \beta \mathrm{Be}$ & $25.75 \beta \mathrm{Bf}$ \\
\hline SUTB & $12.30 \mathrm{\alpha Ba}$ & $13.96 \alpha \mathrm{Bb}$ & $\begin{array}{l}16.52 \mathrm{aBc} \\
10.48 \mathrm{~km} \mathrm{~h}^{-1}\end{array}$ & $18.30 \alpha \mathrm{Bd}$ & $20.86 \alpha \mathrm{Be}$ & $23.33 \alpha \mathrm{Bf}$ \\
\hline FT & $16.31 \beta \mathrm{Ba}$ & $18.73 \beta \mathrm{Cb}$ & $20.35 \beta B c$ & $23.34 \beta C d$ & $25.86 \beta \mathrm{Ce}$ & $28.27 \beta C f$ \\
\hline SUTB & $13.24 \alpha \mathrm{Ca}$ & $15.15 \alpha \mathrm{Cb}$ & $17.59 \alpha \mathrm{Cc}$ & $20.27 \alpha \mathrm{Cd}$ & $23.40 \alpha \mathrm{Ce}$ & $25.59 \alpha \mathrm{Cf}$ \\
\hline \multicolumn{7}{|c|}{$\begin{array}{l}\text { Specific fuel consumption }\left(\mathrm{g} \mathrm{kW}^{-1} \mathrm{~h}^{-1}\right) \\
5.16 \mathrm{~km} \mathrm{~h}^{-1}\end{array}$} \\
\hline FT & $519.03 \beta \mathrm{Ce}$ & $419.27 \beta C d$ & $379.92 \beta B c$ & $346.66 \beta \mathrm{Bb}$ & $326.27 \beta A a$ & $318.51 \beta \mathrm{ABa}$ \\
\hline SUTB & $366.72 \alpha \mathrm{Bd}$ & $321.25 \alpha A c$ & $\begin{array}{l}302.32 \alpha A b \\
7.29 \mathrm{~km} \mathrm{~h}^{-1}\end{array}$ & $284.80 \alpha \mathrm{Aa}$ & $286.09 \alpha \mathrm{Ba}$ & $279.35 \alpha \mathrm{Aa}$ \\
\hline FT & $487.14 \beta \mathrm{Be}$ & $409.03 \beta B d$ & $372.32 \beta B b c$ & $336.46 \beta A b$ & $321.80 \mathrm{BAa}$ & $324.95 \beta \mathrm{Ba}$ \\
\hline SUTB & $362.80 \alpha \mathrm{ABe}$ & $329.58 \alpha \mathrm{Bd}$ & $\begin{array}{l}302.65 \alpha \mathrm{Ac} \\
10.48 \mathrm{~km} \mathrm{~h}^{-1}\end{array}$ & $291.94 \alpha A b$ & $284.30 \alpha \mathrm{ABa}$ & $278.64 \alpha A a$ \\
\hline FT & $457.02 \beta A f$ & $394.34 \beta A e$ & $369.63 \beta \mathrm{Ad}$ & $338.57 \beta A B C$ & $324.27 \beta A b$ & 310.90 ВАа \\
\hline SUTB & $357.59 \alpha \mathrm{Ae}$ & $330.79 \alpha \mathrm{Bd}$ & $305.85 \alpha A c$ & $288.71 \alpha A b$ & $276.21 \alpha \mathrm{Aa}$ & $272.62 \alpha \mathrm{Aa}$ \\
\hline
\end{tabular}

*Averages followed by the same Greek letter in the column between driving strategies, capital letters in the column between travel speeds for the same driving strategy, and lowercase letters in the line do not differ between each other by a Tukey test, considering the nominal value of significance at 0.05 


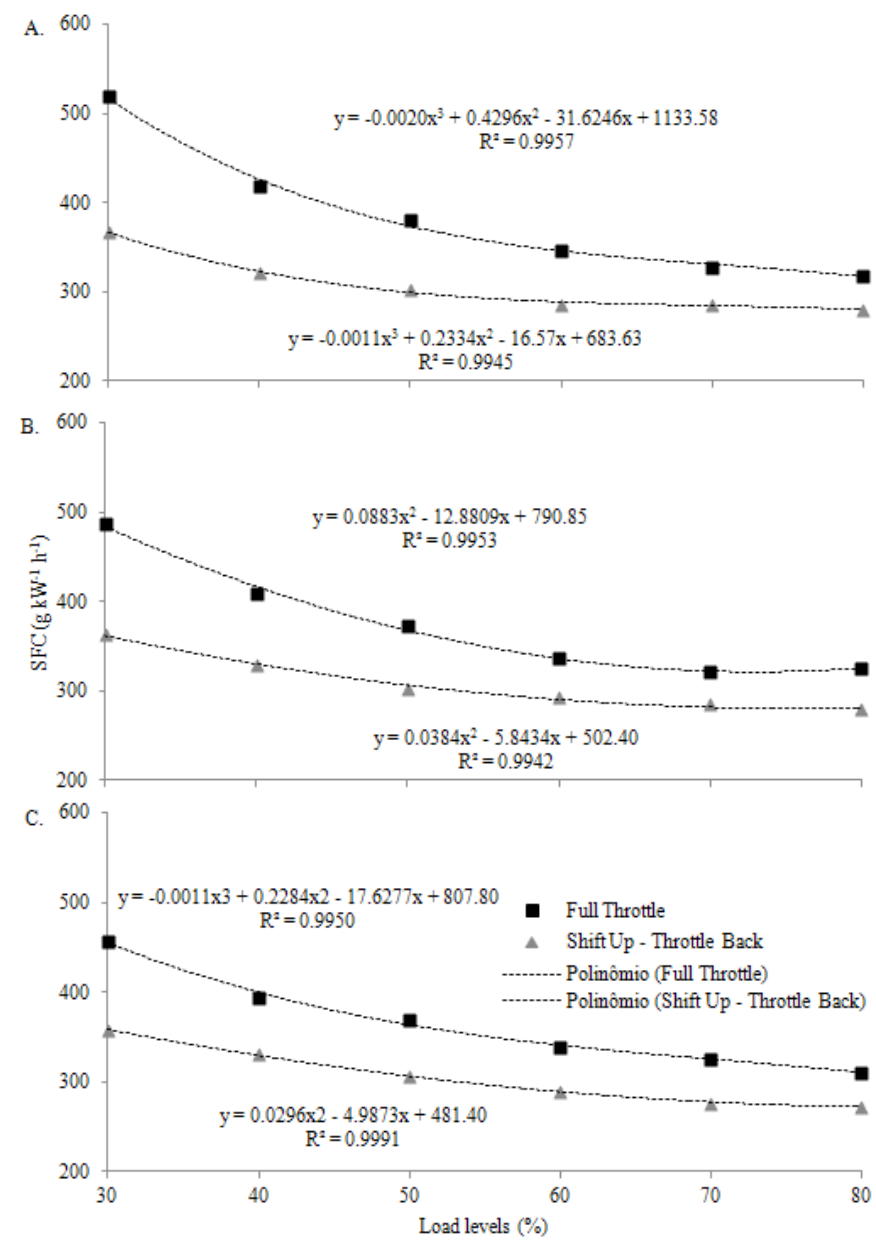

Figure 4. Specific fuel consumption (SFC) regarding the load levels applied to the tractor, using two driving strategies for three travel speeds: (A) 5.16, (B) 7.29 and (C) $10.48 \mathrm{~km} \mathrm{~h}^{-1}$

the ASAE (2006). According to this standard, the SFC is a nonlinear function from the drawbar power. In Figure 4, the high values of the coefficient of determination $\left(\mathrm{R}^{2}\right)$ confirm the adjustment of the polynomial regression curves.

For all treatments evaluated, the SUTB strategy was statistically lower than FT regarding specific fuel consumption, determined by a Turkey test at 0.05 significance (Table 2). For drawbar power levels between 35 and $50 \%$ of maximum power, depending on the travel speed, the SUTB driving strategy of the tractor with Powershift transmission is more efficient than in a tractor with continuously variable transmission (Howard et al., 2013).

For the same travel speed, as load levels increase, the difference in SFC and driving strategies is reduced. This tendency was observed between the three travel speeds used, where the higher the travel speed, the lower the difference (Figure 4).

While analyzing driving strategies in each load level, it is possible to observe that, for all three travel speeds evaluated, the higher the load level applied on the tractor, the lower the specific fuel consumption. According to Acuna et al. (1995), the lowest values of specific fuel are caused by the increased power required of the tractor. Lower specific fuel values mean simultaneous optimization of engine performance, traction efficiency, and the adequacy of the implement for the tractor (Lyne et al., 1984).
It can also be concluded that there is no difference in SFC for heavy load levels (70 and $80 \%$ ), except in FT at $10.48 \mathrm{~km} \mathrm{~h}^{-1}$ (Table 2). According to Márquez (2012), SFC helps assess engine efficiency - in other words, the work that can be produced $\left(\mathrm{kW} \mathrm{h}^{-1}\right)$ from a gram of fuel, regardless of the available engine power.

A tendency is observed where, the higher the travel speed, the lower the specific fuel consumption of the engine (Figure 3 ), but there is a limit in relation to the dynamic traction coefficient, i.e., the traction force to the adherent mass ratio, for each selected work gear. This behavior was found by Lopes et al. (2003), where they report that the gear factor had significant influence on specific fuel consumption, with the variable decreasing while travel speed increased.

Monteiro et al. (2011) obtained a saving of $9.5 \%$ in SFC when the travel speed was increased from 6.5 to $7.5 \mathrm{~km} \mathrm{~h}^{-1}$, through a change of gear from B2 to B3, showing that the travel speed increase improved the tractor's energy yield. In a study performed by Jenane et al. (1996), seventh gear offers a greater opportunity to operate the tractor more efficiently than the fourth gear. Toledo et al. (2010) affirm that mechanized agricultural operations must be planned rationally for an increased profitability in the field.

\section{Conclusions}

1. The knowledge about and use of driving strategies in tractors are alternatives that can make, in general, the rate of fuel spent be reduced, making farm production more profitable and sustainable.

2. SUTB mode must be used as a driving strategy in tractors, because, under the conditions of this experiment, savings of up to $29.39 \%$ of fuel can be obtained when compared with FT, which is normally used by farmers.

\section{ACKnOWledgments}

The authors are grateful to the Coordenação de Aperfeiçoamento de Pessoal de Nível Superior - CAPES for financial support and to the Conselho Nacional de Desenvolvimento Científico e Tecnológico - CNPq for the research productivity scholarship of the second author.

\section{Literature Cited}

Acuña, R. L. D.; Mantovani, E. C.; Martyn, P. J.; Bertaux, S.; Queiroz, D. M. de. Comparação do coeficiente de tração e da eficiência tratória de um trator agrícola obtidos pela equação de Wismer e Luth e por ensaios de campo. Pesquisa Agropecuária Brasileira, v.30, p.523-530, 1995.

ASAE - American Society of Agricultural Engineers. ASAE D497.5: Agricultural Machinery Management. St Joseph: American Society of Agricultural Engineers, 2006. p.343-349.

Estrada, J. S.; Schlosser, J. F.; Farias, M. S.; Rodrigues, F. A.; Martini, A. T.; Santos, G. O. Performance of an agricultural engine using blends of diesel and ethanol. Ciência Rural, v.46, p.1200-1205, 2016. https://doi.org/10.1590/0103-8478cr20150469 
Ferreira, D. F. Sisvar: A computer statistical analysis system. Ciência e Agrotecnologia, v.35, p.1039-1042, 2011. https://doi.org/10.1590/ S1413-70542011000600001

Frantz, U. G.; Schlosser, J. F.; Farias, M. S.; Ferigolo, L. F.; Ebert, L. C. Eficiência energética de um trator agrícola utilizando duas configurações de tomada de potência. Ciência Rural, v.44, p.12191222, 2014. https://doi.org/10.1590/0103-8478cr20130175

Grisso, R.; Pitman, R.; Perumpral, J. V.; Roberson, G. T. “Gear up and throttle down" to save fuel. Blacksburg: Virginia Cooperative Extension, 2014a. 8p. Publication, 442-450

Grisso, R.; Perumpral, J. V.; Roberson, G. T.; Pitman, R. Using tractor test data for selecting farm tractors. Blacksburg: Virginia Cooperative Extension, 2014b. 11p. Publication, 442-072

Hansson, P. A.; Lindgren, M.; Nordin, M.; Pettersson, O. A methodology for measuring the effects of transient loads on the fuel efficiency of agricultural tractors. Applied Engineering in Agriculture, v.19, p.251-257, 2003. https://doi.org/10.13031/2013.13657

Howard, C. N.; Kocher, M. F.; Hoy, R. M.; Blankenship, E. F. Testing the fuel efficiency of tractors with continuously variable and standard geared transmissions. Transactions of the American Society of Agricultural Engineers, v.56, p.869-879, 2013.

IRSTEA - Unité de Recherche Technologies pour la Sécurité et les Performances des Agroéquipements - Centre D’Antony. Test report No 17083: OECD performance test of an agricultural tractor. Paris: IRSTEA, 2013. 39p.

Jenane, C.; Bashford, L. L.; Monroe, G. Reduction of fuel consumption through improved tractive performance. Journal of Agricultural Engineering Research, v.64, p.131-138, 1996. https://doi. org/10.1006/jaer.1996.0054

Kim, Y. J.; Chung, S. O.; Choi, C. H. Effects of gear selection of an agricultural tractor on transmission and PTO load during rotary tillage. Soil \& Tillage Research, v.134, p.90-96, 2013. https://doi. org/10.1016/j.still.2013.07.013

Lindgren, M.; Arrhenius, K.; Larsson, G.; Bäfver, L.; Arvidsson, H.; Wetterberg, C.; Hansson, P.; Rosell, L. Analysis of unregulated emissions from an off-road diesel engine during realistic work operations. Atmospheric Environment, v.45, p.5394-5398, 2011. https://doi.org/10.1016/j.atmosenv.2011.06.046
Lopes, A.; Lanças, K. P.; Furlani, C. E. A.; Nagaoka, A. K.; Castro Neto, P.; Grotta, D. C. C. Consumo de combustível de um trator em função do tipo de pneu, da lastragem e da velocidade de trabalho. Revista Brasileira de Engenharia Agrícola e Ambiental, v.7, p.382-386, 2003. https://doi.org/10.1590/S141543662003000200033

Lyne, P. W. L.; Burt, E. C.; Meiring, P. Effect of tire and engine parameters on efficiency. Transactions of the American Society of Agricultural Engineers, v.27, p.5-11, 1984. https://doi. org/10.13031/2013.32723

Márquez, L. Tractores agrícolas: Tecnología y utilización. Madrid: B\&H Grupo Editorial, 2012. 844p.

Monteiro, L. A.; Lanças, K. P.; Guerra, S. P. S. Desempenho de um trator agrícola equipado com pneus radiais e diagonais equipados com três níveis de lastros líquidos. Engenharia Agrícola, v.31, p.551-560, 2011. https://doi.org/10.1590/S010069162011000300015

OECD - Organization for Economic Cooperation and Development. Code 2: Standard code for the official testing of agricultural and forestry tractor performance. Paris: OECD, 2014. 104p.

Silveira, G. M.; Sierra, J. G. Eficiência energética de tratores fabricados no Brasil. Revista Brasileira de Engenharia Agrícola e Ambiental, v.14, p.418-424, 2010. https://doi.org/10.1590/S141543662010000400011

Stange, K.; Christianson, B.; Alcock, R.; Vik, B. Microcomputer goes to the field to gather tractor test data. Agricultural Engineering, v.65, p.21-26, 1984.

Toledo, A.; Furlani, C. E. A.; Silva, R. P.; Lopes, A.; Dabdoub, M. J. Comportamento espacial da demanda energética em semeadura de amendoim em latossolo sob preparo convencional. Engenharia Agrícola, v.12, p.459-467, 2010. https://doi.org/10.1590/S010069162010000300010

Vale, W. G.; Garcia, R. F.; Corrêa Junior, D.; Gravina, G. A.; Souza, E. F. Desempenho operacional e energético de um trator agrícola durante a operação de roçagem. Global Science and Technology, v.4, p.68-75, 2011. 